\title{
Study of the excretion in bile and concentration in the gall bladder wall of rifamide
}

\author{
G. ACOCElla, F. LAMARINA, L. T. TENCONI, AND F. B. NICOLIS \\ From the Medical Department, Clinical Research Division, Lepetit S.p.A., and \\ Surgical Department A. Ponti, Ospedale Maggiore, Milan (Italy)
}

EDITORIAL COMMENT Studies have been made of the biliary excretion of the antibiotic rifamide in patients with $\mathrm{T}$-tube drainage of the bile ducts. Using a therapeutic dose, the concentration achieved is 100,000 times the minimal inhibitory concentration for Gram-positive and about 100 times that for Gram-negative micro-organisms. Concentrations in the gall bladder were less but were of therapeutic value, particularly with Gram-positive organisms.

Rifamide is a new semisynthetic derivative of the family of rifamycins, a group of antibiotics isolated by Sensi, Margalith, and Timbal in 1959 from the fermentation broths of $S$. mediterranei $n$. sp., which also includes rifamycin SV, fairly widely used in clinical practice.

Rifamide is the diethylamide of rifamycin $B$, one of the compounds which are found in the fermentation broths, and has the following structural formula:-
The chemical and physico-chemical properties of this compound have been described by Maggi, Gallo, and Sensi (1965); it is an orange-yellow crystalline powder of which the sodium salt is soluble in water $(1.5 \mathrm{~g} . / 10 \mathrm{ml}$.).

Toxicological studies were carried out in laboratory animals by Dezulian, Serralunga, and Maffii (1966). The $\mathrm{LD}_{50}$ of rifamide administered subcutaneously has been shown to be of the order of $640 \mathrm{mg} . / \mathrm{kg}$. in mice, $2,500 \mathrm{mg} . / \mathrm{kg}$. in rats and

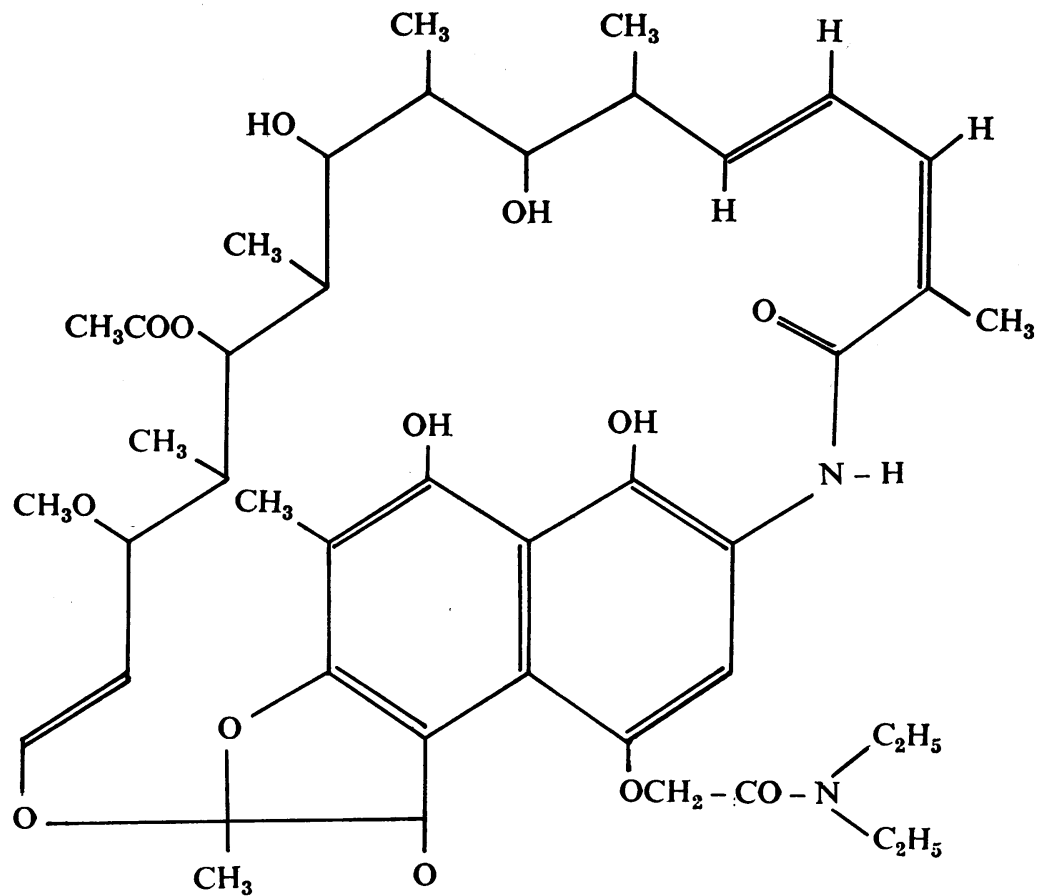


rabbits, and $425 \mathrm{mg} . / \mathrm{kg}$. in dogs. The intravenous $\mathrm{LD}_{50}$ values in these animals were found to be of the order of 315 to $550 \mathrm{mg} . / \mathrm{kg}$.

In chronic toxicity tests, dogs treated intravenously with $50 \mathrm{mg} . / \mathrm{kg}$. of rifamide twice daily for six months did not show any sign of disease due to the compound (Dezulian et al., 1966).

Rifamide shows antimicrobial activity mainly against Gram-positive organisms. In vitro, minimal inhibitory concentrations have been shown to be of the order of 0.01 to $0.02 \mu \mathrm{g}$. $/ \mathrm{ml}$. for Staphylococcus aureus, 0.05 to $0.1 \mu \mathrm{g} . / \mathrm{ml}$. for Streptococcus, and $0.02 \mu \mathrm{g} . / \mathrm{ml}$. for Diplococcus pneumoniae.

As far as Gram-negative micro-organisms are concerned, minimal inhibitory concentrations have been found to be of the order of $20 \mu \mathrm{g} . / \mathrm{ml}$. for $E$. coli, Aerobacter aerogenes, Proteus vulgaris and morganii, Salmonella typhi, and Shigella dysenteriae.

Further data on antimicrobial activity of rifamide are reported in the papers by Pallanza, Fürész, Timbal, and Carniti (1965), and Fürész, Arioli, and Scotti (1965).

Distribution studies carried out in animals have shown that rifamide, like other members of the rifamycin family, is excreted in high degree in the bile (Maffii and Schiatti, 1966). In rats given 5 to 10 and $25 \mathrm{mg} . / \mathrm{kg}$. intravenously, from 56 to $84 \%$ of the dose was recovered in the bile produced within two hours after administration.

On the basis of low toxicity, good antimicrobial activity, and high biliary excretion of rifamide, this study was undertaken in order to establish whether the antibiotic could be used therapeutically in man in infections of the biliary tree. We also intended to evaluate the possible effects of the treatment on certain components of human bile.

A series of experiments has therefore been carried out in man in order to evaluate the biliary excretion of rifamide after repeated intramuscular administration; the possible effects of the treatment on the bile volume and on the biliary excretion of bilirubin and cholesterol; and the concentration of rifamide in the gall bladder wall.

\section{MATERIAL AND METHODS}

EXCRETION OF RIFAMIDE AND EFFECT ON SOME BILE VARIABLES This study was carried out in four subjects with biliary drainage ( $T$ tube) on the sixth to seventh days after cholecystectomy. Rifamide was administered intramuscularly at a dose of $150 \mathrm{mg}$. every eight hours. For each subject the experiment was divided into a treatment period and a control period of 24 hours each, in order to avoid spontaneous variations of certain parameters under study, e.g., bile volume in relation to meals or periods of sleep, which could affect the results. In two subjects ( 3 and 4 ) the observations were continued for a further period of 24 hours. The periods of treatment and control were assigned in different sequences, according to a cross-over design.

Bile was collected every hour, the volume measured, and each sample was assayed for the following components:-

Rifamide The assays have been carried out by the agar plate method using Staphylococcus aureus ATCC 6538 as test organism (Fürész et al., 1965). Rifamide concentration is expressed in $\mu \mathrm{g} . / \mathrm{ml}$. The recovery, per hour and cumulative, has been calculated and expressed in milligrams.

Bilirubin Bile samples were diluted 1:20 and analysed for bilirubin content by the method of Malloy and Evelyn (1937). A preliminary study showed that, in these conditions, rifamide does not interfere in the diazo determination of bilirubin. The concentration of bilirubin in bile is expressed in terms of $\mathrm{mg} . / 100 \mathrm{ml}$. The excretion, per hour and cumulative, has been calculated.

Cholesterol The assays have been carried out by the method of Sperry and Webb (1950) after extraction of cholesterol carried out according to the method of Foldes (1943). Cholesterol concentrations (mg./100 ml.) per hour and cumulative excretion (mg.) have been calculated.

The data on the volume of the bile drained and on the biliary concentration of bilirubin and cholesterol were analysed by means of an analysis of variance (Snedecor, 1961). The experiments have been analysed as split-plots (Cochran and Cox, 1957) on the basis that once the period of observation was assigned (control or treatment), the observations corresponding to the different times could not occur in random order.

CONCENTRATION OF RIFAMIDE IN THE GALL BLADDER WALL This study was carried out in 16 subjects who underwent operation for cholecystectomy. Rifamide was administered at the dose of $150 \mathrm{mg}$. every eight hours intramuscularly, during a period ranging from one day to eight days before the operation.

Gall bladders were collected and kept in sterile tubes. They were cut, washed with saline, weighed and crushed with quartz grains in a mortar. A homogenate, 1:10 w/v with saline, was prepared and after centrifugation a microbiological assay was carried out on the supernatant using the method described for bile assay. The concentration of rifamide in the gall bladder has been expressed as $\mu \mathrm{g} . / \mathrm{g}$. of tissue and $\mu \mathrm{g} . /$ organ.

RESULTS

EXCRETION OF RIFAMIDE Biliary concentrations of rifamide are presented in Figures 1 to 4 . Peak bile concentrations occurred, in general, at three to four hours after injection, ranging between 1,100 and $2,400 \mu \mathrm{g}$. $/ \mathrm{ml}$. Minimal concentrations of the order of $200 \mu \mathrm{g} . / \mathrm{ml}$. have been generally observed during the hour preceding each administration following the first. From the data reported in Fig. 4 it can be seen that, at 32 hours after injection, concentrations of about $8 \mu \mathrm{g} . / \mathrm{ml}$. were still present in the bile. In order to evaluate whether any modification had 


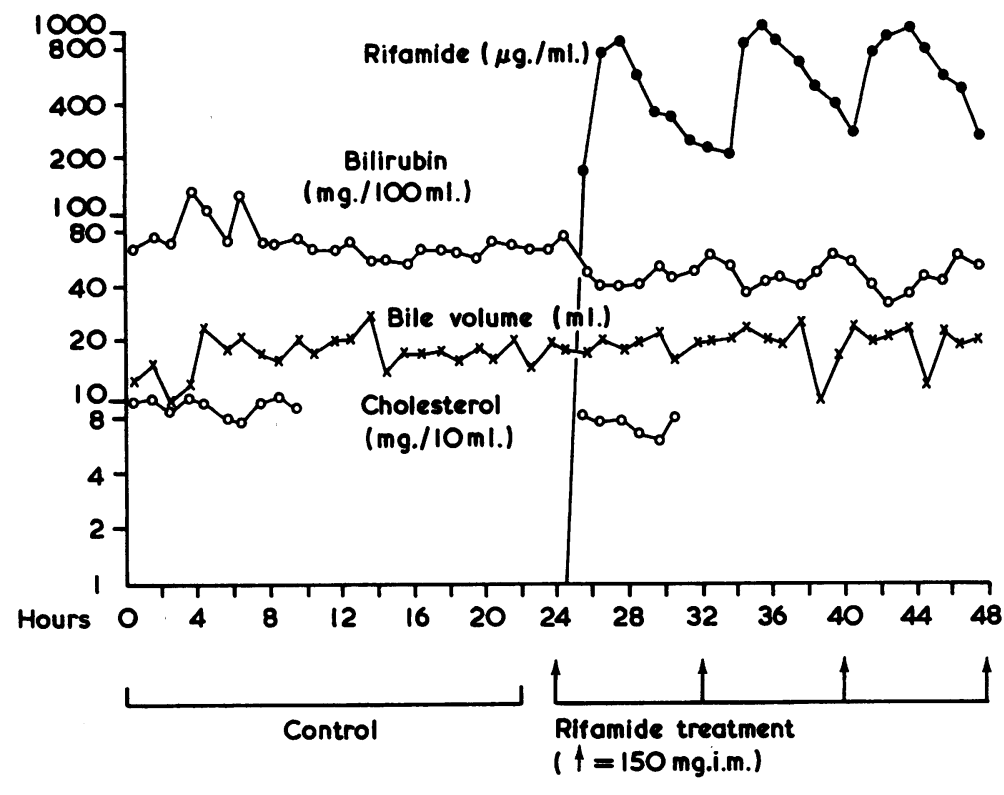

FIG. 1. Bile volume and biliary excretion of rifamide, bilirubin, and cholesterol in case 1 with biliary drainage during treatment with rifamide (150 ml./8 hr. i.m.) and a control period.

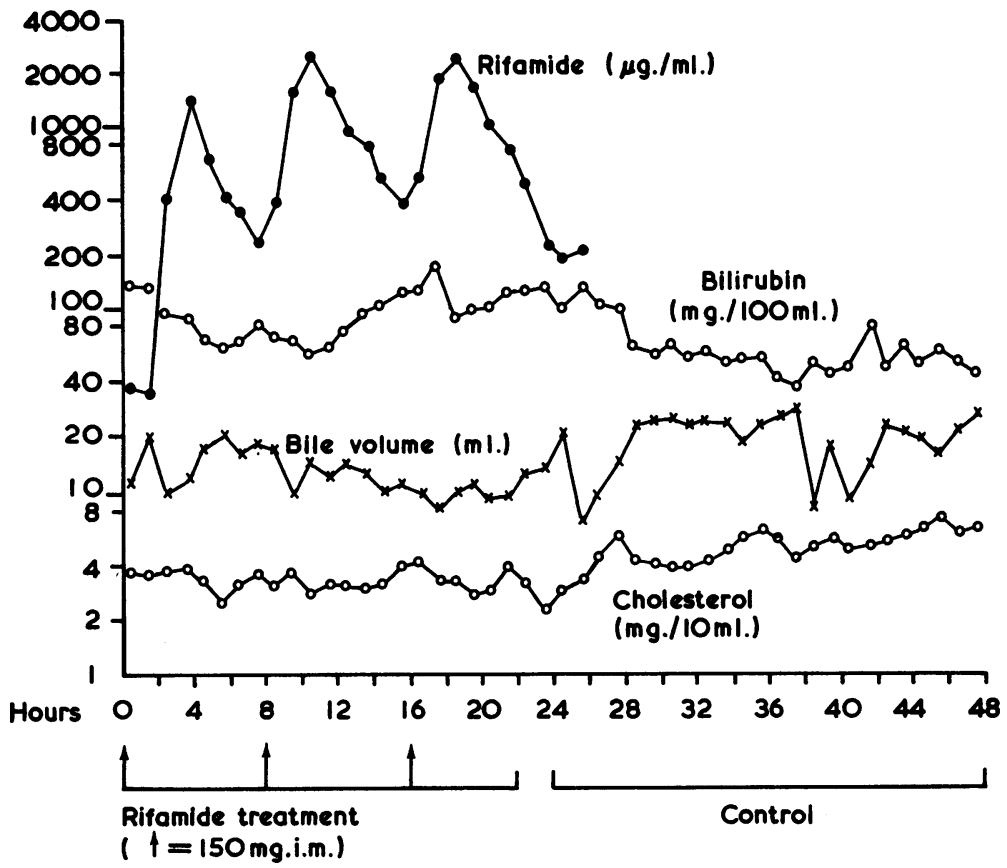

FIG. 2. Bile volume and biliary excretion of rifamide, bilirubin, and cholesterol in case 2 with biliary drainage during treatment with rifamide (150 ml./8 hr. i.m.) and a control period. 

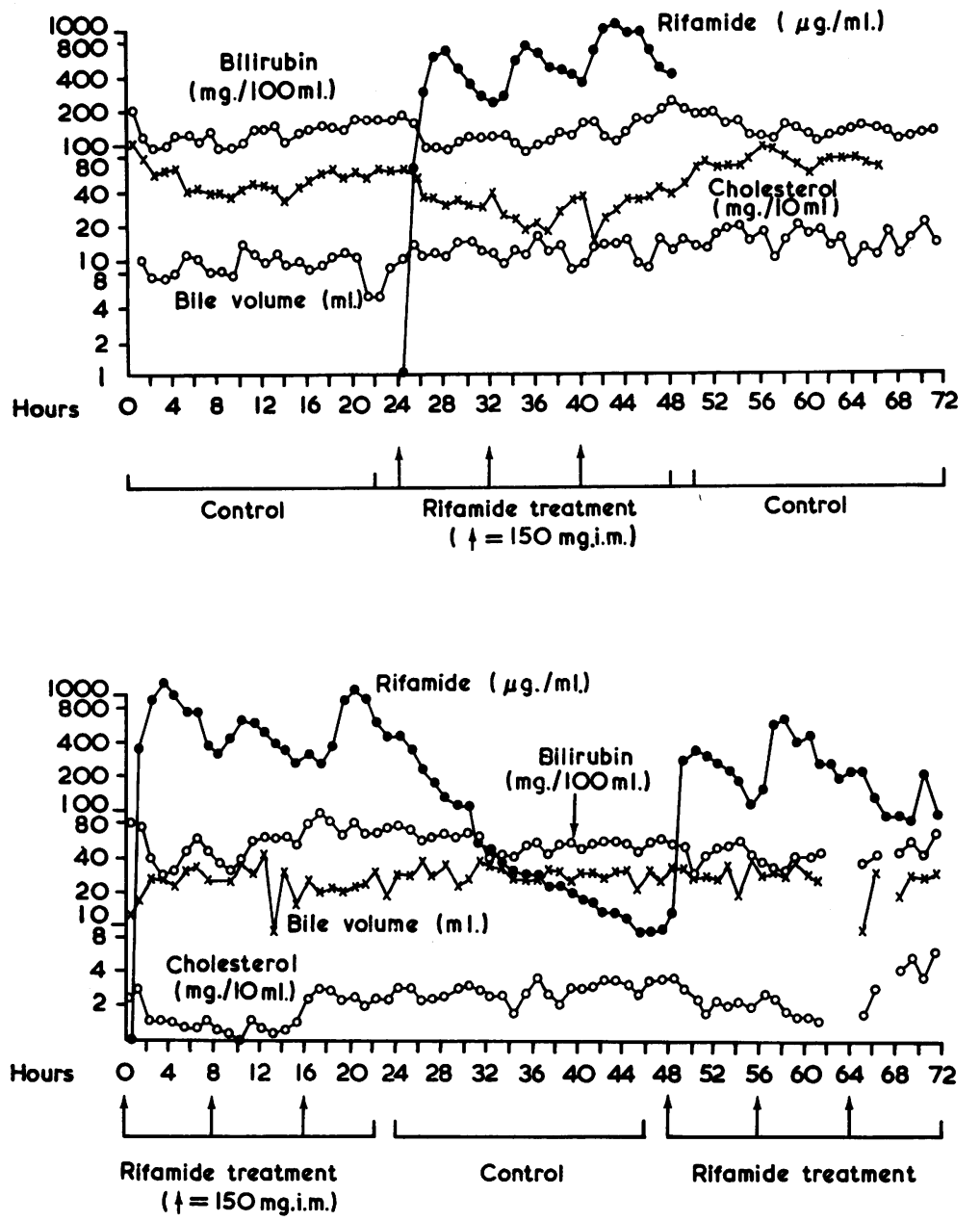

FIG. 3. Bile volume and biliary excretion of rifamide, bilirubin, and cholesterol in case 3 with biliary drainage during treatment with rifamide $(150 \mathrm{ml} . / 8 \mathrm{hr}$. i.m.) and a control period.

FIG. 4. Bile volume and biliary excretion of rifamide, bilirubin, and cholesterol in case 4 with biliary drainage during treatment with rifamide (150 ml./8 hr. i.m.) and a control period. occurred in the molecular structure of rifamide after passage through the liver, an amount of rifamide corresponding to that determined microbiologically was added to bile free of rifamide taken from case 2 before treatment. Both specimens were run on thinlayer chromatography. Both the spot corresponding to the rifamide added and that corresponding to the rifamide present in bile after secretion by the liver showed the same $R_{\mathfrak{f}}$, size, and colour features.

The recovery per hour of rifamide follows the pattern of the concentration in bile, in the sense that, for both, the maximal and minimal values occurred at the same time intervals. There is no evidence of accumulation phenomena. Total recovery of rifamide ranged between 55 and $57 \%$ of the administered dose.

EFFECT OF RIFAMIDE TREATMENT ON CERTAIN BILE VARIABLES These will be considered separately for bile volume, bilirubin excretion, and cholesterol excretion.

Bile volume The data on bile volume are set out in Table $I$ and Figures 1 to 4. Mean values per hour ranged between 11.5 and $25.0 \mathrm{ml}$. during rifamide treatment and between 11.2 and $28.7 \mathrm{ml}$. during the control period. The results of the statistical analysis (Table II) show that the difference between the values observed during the two periods of observation are far from being statistically significant.

Bilirubin excretion Biliary concentrations and excretion for each hour are reported in Table I and Figures 1 to 4 . Mean concentration values ranged between 45.3 and $120.3 \mathrm{mg}$. $/ 100 \mathrm{ml}$. during treatment with rifamide, and between 52.2 and $134.1 \mathrm{mg} . / 100$ $\mathrm{ml}$. during the control period. The differences between the mean values of the two periods are far from statistical significance (Table III); the significance of the times $\times$ treatments interaction does 
TABLE I

BILE VOLUME AND BILIRUBIN EXCRETION IN FOUR SUBJECTS WITH BILIARY DRAINAGE (T TUBE) DURING RIFAMIDE TREATMENT AND DURING A CONTROL PERIOD OF 24 HOURS ${ }^{1}$

\begin{tabular}{|c|c|c|c|c|c|c|c|}
\hline \multirow{2}{*}{$\begin{array}{l}\text { Subject } \\
\text { No. }\end{array}$} & \multirow[t]{2}{*}{ Sequence } & \multicolumn{2}{|c|}{ Bile Volume (ml./hour) } & \multicolumn{2}{|c|}{ Bilirubin Concentration ( $\mathrm{mg} . / 100 \mathrm{ml}$ ) } & \multicolumn{2}{|c|}{ Bilirubin Excretion (mg./hr.) } \\
\hline & & Rifamide & Control & Rifamide & Control & Rifamide & Control \\
\hline $\begin{array}{l}1 \\
2 \\
3^{2}\end{array}$ & $\begin{array}{l}\mathbf{C}-\mathbf{R} \\
\mathbf{R}-\mathbf{C} \\
\mathbf{C}-\mathbf{R}\end{array}$ & $\begin{array}{l}18.9 \pm 3.2 \\
13.0 \pm 3.5 \\
11.5 \pm 1.9\end{array}$ & $\begin{array}{r}17.3 \pm 3.6 \\
19.4 \pm 6.2 \\
8.7 \pm 2.2 \\
(14.0 \pm 2.9)\end{array}$ & $\begin{array}{r}45.3 \pm 8.5 \\
97.0 \pm 30.3 \\
120.3 \pm 39.4\end{array}$ & $\begin{array}{r}71.0 \pm 13.3 \\
60.7 \pm 25.4 \\
131.9 \pm 25.8 \\
(136.7 \pm 28.9)\end{array}$ & $\begin{array}{r}8.5 \pm 1.8 \\
12.2 \pm 4.0 \\
14.3 \pm 4.1\end{array}$ & $\begin{array}{l}12.3 \pm 4.2 \\
10.9 \pm 3.6 \\
11.2 \pm 3.0 \\
(18.9 \pm 5.4)\end{array}$ \\
\hline $4^{2}$ & $\mathbf{R}-\mathbf{C}$ & $\begin{array}{c}23 \cdot 8 \pm 7 \cdot 5 \\
(27 \cdot 3 \pm 6 \cdot 4)\end{array}$ & $28 \cdot 7 \pm 4 \cdot 1$ & $\begin{array}{r}50.7 \pm 20.4 \\
(43.0 \pm 7.0)\end{array}$ & $49.2 \pm 8.6$ & $\begin{aligned} 12.3 & \pm 4.7 \\
(11.7 & \pm 3.3)\end{aligned}$ & $15.0 \pm 2.8$ \\
\hline
\end{tabular}

${ }^{1}$ Means \pm S.D.

$\mathbf{C}=$ control period; $\mathbf{R}=$ rifamide treatment period.

'Within brackets are reported the values observed during a third, supplementary 24-hour period of observation, carried out on subjects nos. 3 and 4.

TABLE II

ANALYSIS OF VARIANCE OF THE DATA ON BILE VOLUME SUMMARIZED IN TABLE I

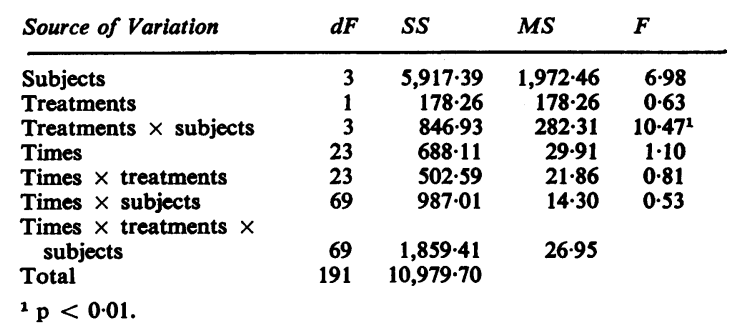

TABLE III

ANALYSIS OF VARIANCE OF THE DATA ON BILIRUBIN CONCENTRATION IN BILE SUMMARIZED IN TABLE I

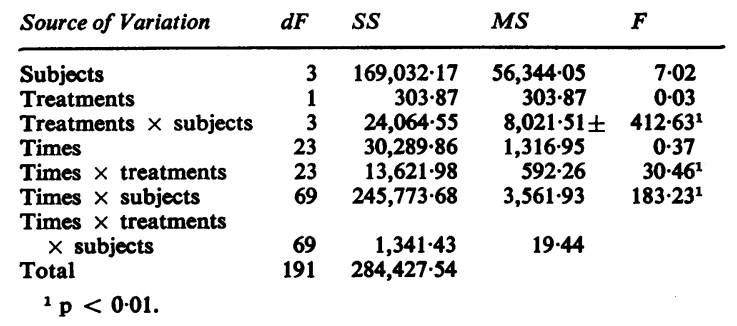

not seem to be very relevant to the purposes of our analysis. The values are in agreement with those reported by previous authors (Popper and Schaffner, 1960). In cases 1-3 and 4 there is some evidence that the maximal concentration of rifamide corresponded to the minimal concentration of bilirubin and vice versa; however, a significant negative correlation between the two variables could not be demonstrated.

Mean values of bilirubin excretion per hour ranged between 8.5 and $14.3 \mathrm{mg}$. during treatment with rifamide and between 10.9 and $15.0 \mathrm{mg}$. during the control period.

The cumulative excretion, in 24 hours, ranged between 204.5 and $360.7 \mathrm{mg}$.

Cholesterol excretion Biliary concentrations and excretion for each hour are reported in Table IV and Figures 1-4. In order to avoid overlapping of curves, on Figs. 2, 3, and 4 the values of cholesterol concentration in bile are expressed as $\mathrm{mg} . / 10 \mathrm{ml}$. bile.

The mean values for cholesterol concentration ranged between 21.1 and $69.1 \mathrm{mg} . / 100 \mathrm{ml}$. during the treatment with rifamide, and between 26.9 and $92.6 \mathrm{mg}$. during the control period.

The results of the statistical analysis, carried out only on the values for cases 2,3 , and 4 , as case 1

TABLE IV

EXCRETION OF CHOLESTEROL IN THE BILE OF FOUR SUBJECTS DURING RIFAMIDE TREATMENT AND DURING A CONTROL PERIOD ${ }^{1}$

\begin{tabular}{|c|c|c|c|c|c|}
\hline \multirow{2}{*}{$\begin{array}{l}\text { Subject } \\
\text { No. }\end{array}$} & \multirow{2}{*}{$\begin{array}{l}\text { Hours of Observation } \\
\text { during Each of Two Periods }\end{array}$} & \multicolumn{2}{|c|}{ Cholesterol Concentration ( $\mathrm{mg} . / 100 \mathrm{ml}$.) } & \multicolumn{2}{|c|}{ Cholesterol Excretion (mg./hr.) } \\
\hline & & Rifamide & Control & Rifamide & Control \\
\hline $\begin{array}{l}1 \\
2 \\
3^{2}\end{array}$ & $\begin{array}{r}6 \\
24 \\
24\end{array}$ & $\begin{array}{l}69.1 \pm 8.8 \\
32.7 \pm 4.5 \\
29.7 \pm 10.4\end{array}$ & $\begin{array}{c}92.6 \pm 13.4 \\
50.5 \pm 10.5 \\
51.6 \pm 16.5 \\
(63.7 \pm 11.7)\end{array}$ & $\begin{array}{r}12.8 \pm 1.2 \\
4.2 \pm 1.1 \\
3.4 \pm 1.2\end{array}$ & $\begin{array}{r}14.9 \pm 4.3 \\
9.9 \pm 3.7 \\
4.3 \pm 1.3 \\
(8.7 \pm 2.4)\end{array}$ \\
\hline $4^{2}$ & 24 & $\begin{array}{l}17 \cdot 8 \pm 6 \cdot 0 \\
(24 \cdot 3 \pm 11 \cdot 3)\end{array}$ & $26.9 \pm 3.6$ & $\begin{array}{c}4.1 \pm 1.3 \\
(6.9 \pm 3 \cdot 0)\end{array}$ & $7 \cdot 7 \pm 1 \cdot 3$ \\
\hline
\end{tabular}

${ }^{1}$ Mean \pm S.D.

'Within brackets are reported the values observed during a third, supplementary 24-hour period of observation, carried out on subjects nos. 3 and 4. 
TABLE V

ANALYSIS OF VARIANCE OF THE DATA ON CHOLESTEROL CONCENTRATION IN BILE SUMMARIZED IN TABLE IV

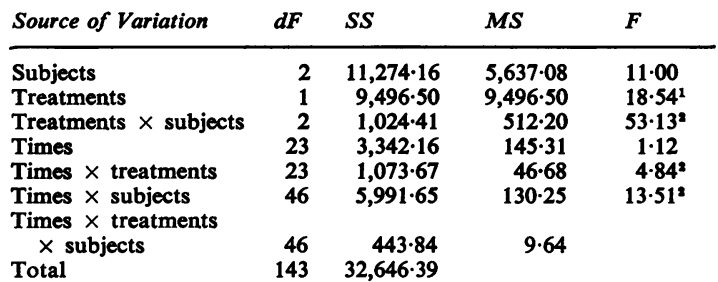

$1 \mathrm{p}<0.05$.

$8 \mathrm{p}<0.01$

was studied only for six hours, are reported in Table V. From these data it can be seen that the differences between the two periods are statistically significant.

The excretion per hour of cholesterol is also decreased during the treatment with rifamide.

CONCENTRATION OF RIFAMIDE IN THE GALL BLADDER WALL The data are reported in Table $V$. The minimum and maximum values have been, respectively, 14 and $78 \mu \mathrm{g} . / \mathrm{g}$. of tissue. As total content the values ranged between 140 and $972 \mu \mathrm{g}$./organ. There is no evidence that the concentration in the gall bladder wall is affected by the duration of treatment.

\section{TABLE VI}

RIFAMIDE CONTENT IN THE GALL BLADDER WALL AFTER INTRAMUSCULAR ADMINISTRATION OF 150 MG. EVERY EIGHT HOURS IN MAN

\begin{tabular}{cccc} 
Subject No. & $\begin{array}{l}\text { Days of } \\
\text { Treatment }\end{array}$ & $\begin{array}{l}\text { Concentration } \\
(\mu \mathrm{g} . / \mathrm{g} .)\end{array}$ & $\begin{array}{l}\text { Total Content } \\
(\mu \mathrm{g} .)\end{array}$ \\
\hline 1 & 1 & 14 & 140 \\
2 & 1 & $23^{1}$ & 184 \\
3 & 1 & 19 & 209 \\
4 & 1 & 44 & 616 \\
5 & 1 & 25 & 366 \\
6 & 2 & 69 & 911 \\
7 & 2 & 42 & 338 \\
8 & 3 & 78 & 706 \\
9 & 3 & 35 & 425 \\
10 & 3 & 43 & 337 \\
11 & 3 & 22 & 770 \\
12 & 3 & 48 & 528 \\
13 & 4 & 55 & 664 \\
14 & 6 & 54 & 972 \\
15 & 7 & 36 & 447 \\
16 & 8 & 23 & 599 \\
Mean & standard deviation & $39 \cdot 4 \pm 18.4$ & $513.2 \pm 251 \cdot 4$
\end{tabular}

${ }^{1}$ Rifamide concentrations in cholecistic bile $336 \mu \mathrm{g} . / \mathrm{ml}$.

\section{DISCUSSION AND CONCLUSIONS}

A comparison between the antimicrobial activity of rifamide and the levels found in the bile suggests that

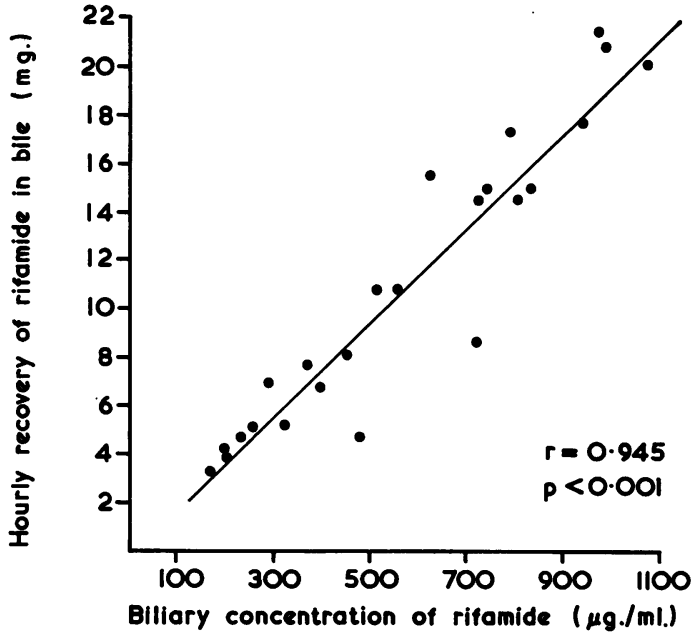

FIG. 5. Correlation between concentration and recovery of rifamide in human bile during a period of 24 hours. Recovery is calculated as the product of concentration by volume of bile drained in each hour.

this compound, given intramuscularly at the dose of $150 \mathrm{mg}$. every eight hours, can be useful in the treatment of biliary tract infections sustained by Grampositive and/or Gram-negative organisms. In fact, the maximum concentrations of rifamide in bile is about 100,000 times the minimum concentration for Gram-positive and about 100 times that for Gramnegative micro-organisms.

The recovery of rifamide in bile ranged between 55 and $57 \%$. If one takes into account that the bile actually produced by the liver is not completely drained through the $T$ tube and that at the end of the determination period the bile still contained rifamide, it is apparent that the amount of rifamide excreted by the liver is greater than these estimates.

The variations in bile volume do not appear to have any appreciable influence on the concentration and recovery of rifamide, which always showed a close correlation (Fig. 5).

The chromatographic results suggest that rifamide is excreted in the bile without modifications and also confirm quantitatively the values of the microbiological determination.

In our experimental conditions there has been some evidence of an increase of bile volume with time, which could be interpreted as an expression of the functional recovery of the liver after surgery, and that was not affected by the treatment with rifamide. This trend was accompanied by a corresponding slightly decreasing trend in bilirubin concentration, which could be explained on the basis of the increase of the volume of bile, as the amount of bilirubin 
formed in the reticuloendothelial cells from haemoglobin could be considered as a constant.

A significant effect of rifamide on the excretion of bilirubin in the bile has not been shown, either by comparison of the bilirubin excretion in the treatment period with that in the control period, or by the study of the correlation between the values obtained for the two variables during the treatment period. However, the possibility of a slight influence of rifamide on the time course of the bilirubin concentration in the bile may not entirely be excluded, as the highest values for one variable generally correspond to the lowest values for the other.

The interpretation of the significant decrease in cholesterol excretion during rifamide treatment remains, at the moment, obscure. Experiments are in progress in order to assess the relationship between rifamide treatment and cholesterol metabolism. Preliminary results show that the excretion of cholates in bile is not affected by treatment with rifamide.

The values for concentrations of rifamide in the gall bladder wall suggest the possibility that the drug diffuses in the wall both from blood and from bile.

In our cases, the cystic duct was always patent but the gall bladders contained a great number of stones. This fact resulted in a remarkable decrease of the space available for the bile entering the gall bladder from the liver and containing high concentrations of rifamide. For this reason, it may be speculated that the contribution of the rifamide contained in the bile to the concentrations in the gall bladder wall was inferior to what could be expected on the basis of the very high biliary concentrations when no stones are present in the gall bladder. However, the levels obtained in the gall bladder wall are of therapeutic value, particularly as far as Gram-positive microorganisms are concerned.

We wish to thank Professor Sheila Sherlock, of the Royal Free Hospital, London, for her advice and suggestions, and Professor S. Fürész, of the Department of Bacteriology, Lepetit S.p.A., for his help in the rifamide assays.

\section{REFERENCES}

Cochran, W. G., and Cox, G. M. (1957). Experimental Designs, 2nd ed., p. 293. Wiley, New York.

Dezulian, V., Serralunga, M. G., and Maffii, G. (1966). Rifamycins XXXIX. Rifamycin B diethylamide (rifamide) pharmacology and general toxicology. Toxicol. appl. Pharmacol., 8, 126-137.

Foldes, F. F. (1943). The quantitative determination of combined cholesterol in the presence of bile. J. Lab. clin. Med., 28, 18891891.

Fürész, S., Arioli, V., and Scotti, R. (1965). Rifamycin B diethylamide (rifamide): activity in experimental infections, absorption and elimination in man. Arzneimittel-Forsch., 15, 802-804.

Maffii, G. and Schiatti, P. (1966). Rifamycins XL. Rifamycin B diethylamide (rifamide): distribution and excretion in rats and dogs. Toxicol. appl. Pharmacol., 8, 138-151.

Maggi, N., Gallo, G. G., and Sensi, P. (1965). Rifamicina XXXVI. Proprietà chimiche e chimico-fisiche della dietilamide della rifamicina B. Farmaco, Ed. prat., 20, 147-153.

Malloy, H. T., and Evelyn, K. A. (1937). The determination of bilirubin with the photoelectric colorimeter. J. biol. Chem., $119,481-490$.

Pallanza, R., Fürész, S., Timbal, M. T., and Carniti, G. (1965). Rifamycin XXXVII. In vitro bacteriological studies on rifamycin B diethylamide (rifamide). Arzneimittel-Forsch., 15, 800-802.

Popper, H., and Schaffner, F. (1960). Fegato. Struttura e funzione, p. 176. Il Pensiero Scientifico, Rome.

Sensi, P., Margalith, P., and Timbal, M. T. (1959). Rifomycin, a new antibiotic. Preliminary report. Farmaco, Ed. sci., 14, 146-147.

Snedecor, G. W. (1961). Statistical Methods, 5th ed., p. 150. The Iowa State University Press, Ames, Iowa.

Sperry, W. M., and Webb, M. (1950). A revision of the SchoenheimerSperry method for cholesterol determination. J. biol. Chem., 187, 97-106. 